\title{
THE EFFECTS OF WATER VAPOR ON THE OXIDATION OF NICKEL-BASE SUPERALLOYS AND COATINGS AT TEMPERATURES FROM $700^{\circ} \mathrm{C}$ TO $1100^{\circ} \mathrm{C}$
}

\author{
K. Onal, M. C. Maris-Sida, G. H. Meier, F. S. Pettit \\ University of Pittsburgh, Pittsburgh, PA \\ Keywords: water vapor, oxidation, $\alpha-\mathrm{Al}_{2} \mathrm{O}_{3}$ - forming superalloys, coatings, chromia-forming superalloys
}

\begin{abstract}
The oxidation of superalloys that rely upon the development of $\alpha$ $\mathrm{Al}_{2} \mathrm{O}_{3}$ or $\mathrm{Cr}_{2} \mathrm{O}_{3}$ scales for oxidation resistance in air containing water vapor are compared at temperatures from $700^{\circ} \mathrm{C}$ to $1100^{\circ} \mathrm{C}$. It is shown that water vapor affects the oxidation of such alloys in different ways. Water vapor adversely affects the selective oxidation of aluminum in the $\alpha-\mathrm{Al}_{2} \mathrm{O}_{3}$-formers, and also affects the adherence of these oxide scales. The major effect of water vapor on the chromia-formers is enhanced vaporization of $\mathrm{Cr}_{2} \mathrm{O}_{3}$. Aluminide coated superalloys are also examined in these cyclic oxidation tests, and it will be shown that water vapor caused spalling of the $\alpha-\mathrm{Al}_{2} \mathrm{O}_{3}$ scales, but the effect is small for strongly adherent $\alpha-\mathrm{Al}_{2} \mathrm{O}_{3}$ scales.
\end{abstract}

\section{Introduction}

Water vapor is present in almost all environments unless precautions are taken to exclude it. Furthermore, water vapor has been found to affect the oxidation of alloys and coatings. The effects produced by water vapor depend upon the type of oxide that is formed and the experimental conditions [1-15] (e.g. temperature, water vapor pressure). Most superalloys and coatings for superalloys rely on the formation of $\alpha$-alumina or chromia scales for oxidation resistance at temperatures above $700^{\circ} \mathrm{C}$. This paper is concerned with the effects of water vapor on the oxidation of superalloys and coatings for superalloys that develop oxidation resistance via the formation of $\alpha-\mathrm{Al}_{2} \mathrm{O}_{3}$ or $\mathrm{Cr}_{2} \mathrm{O}_{3}$ scales.

\section{Experimental}

The compositions of the superalloys that were studied in cyclic oxidation are presented in Table I. Aluminide and platinum modified aluminide coatings on René N5 were also studied in cyclic oxidation. These studies were performed using coupon specimens with areas about $1 \mathrm{~cm}^{2}$ and $0.3 \mathrm{~cm}$ thick. The experimental procedures have been discussed previously [16]. The specimens were cyclically exposed in the hot zone of a horizontal tube furnace for 45 minutes and 15 minutes in a cool zone $\left(200^{\circ} \mathrm{C}\right)$ outside of the furnace. Experiments were performed in dry air and in air with pressures of 0.1 or 0.5 atm water vapor. The test temperatures extended from $700^{\circ} \mathrm{C}$ to $1100^{\circ} \mathrm{C}$, but the chromia-forming superalloys were not tested at $1100^{\circ} \mathrm{C}$. The cyclic oxidation resistances of the alloys were evaluated using weight-change versus time measurements and metallographic observations of exposed specimens. In order to account for the observed degradation of these alloys some studies were also performed on more simple binary and ternary alloys containing $\mathrm{Ni}-\mathrm{Cr}$ and Ni-Cr-Al.

\section{Results and Discussion}

The results from these investigations will be presented by first discussing the $\alpha$-alumina-forming superalloys, which will be followed by results for the chromia-forming alloys, and then finally the results obtained with the aluminide coatings.

\section{Alpha-Alumina-Forming Superalloys:}

Weight change versus time data for the cyclic oxidation of PWA 1484, MarM 247, CM 186 and René N5 at $700^{\circ} \mathrm{C}, 900^{\circ} \mathrm{C}$ and $1000^{\circ} \mathrm{C}$ in dry and wet air are presented in Figures 1, 2 and 3, respectively. At $700^{\circ} \mathrm{C}$ the weight gains for PWA 1484, MarM 247 and CM 186 were larger in wet air than in dry air. There was not a large difference between the weight changes for N5 in wet and dry air, Figure 1. Metallographic examination of the specimens that were exposed at $700^{\circ} \mathrm{C}$ showed that continuous layers of $\alpha-\mathrm{Al}_{2} \mathrm{O}_{3}$ were not present on any of the alloys but substantial amounts of $\mathrm{NiO}$ and internal oxides of aluminum had been formed, Figure 4, especially on the specimens that exhibited the larger weight gains.

At $900^{\circ} \mathrm{C}$ there was not a large difference between the weight change versus time curves for dry and wet air, Figure 2. For both conditions, it was apparent for all of the alloys that some cracking and spalling of the $\alpha-\mathrm{Al}_{2} \mathrm{O}_{3}$ scales had occurred followed by transient oxidation with development of the $\alpha-\mathrm{Al}_{2} \mathrm{O}_{3}$ scales beneath these transient oxides, Figure 5.

At $1000^{\circ} \mathrm{C}$ the weight gain versus time curves for CM 186 and MarM 247 were significantly larger than those for PWA 1484 and N5. This was the case for both wet and dry air, Figure 3. At this temperature it was found that a substantial amount of $\mathrm{HfO}_{2}$ was formed as an internal network of oxide, Figure 6, in MarM 247 and CM 186 but not in PWA 1484 and N5, Figure 7. There was some spalling of oxide scales from all of these alloys but oxide scales rich in aluminum were evident on all of the specimens, Figures 6 and 7. The larger weight gains for MarM 247 and CM 186 are due to the larger Hf concentrations for these two alloys compared to PWA 1484 and N5 whereby a large amount of oxygen can enter the former alloys due to rapid diffusion of oxygen in the $\mathrm{HfO}_{2}$ network.

Only N5 was tested in cyclic oxidation at $1100^{\circ} \mathrm{C}$. Two versions of N5 were tested, one with 5-8 ppm sulfur and another with less than $1 \mathrm{ppm}$ sulfur. The results obtained in the cyclic oxidation test are presented in Figure 8 . The presence of water vapor caused the oxide scale formed on N5 (5-8 ppm sulfur) to crack and spall but water vapor did not have any effect on the cyclic oxidation 
Table I. Composition of Alloys in Weight Percent

\begin{tabular}{|c|c|c|c|c|c|c|c|c|c|c|c|c|c|c|}
\hline Alloy & $\mathrm{Ni}$ & $C r$ & $A l$ & Co & $T a$ & $\boldsymbol{W}$ & Mo & $T i$ & $B$ & $C$ & $H f$ & $Z r$ & $\mathrm{Nb}$ & $R e$ \\
\hline IN 738 & Bal. & 16.0 & 3.4 & 8.5 & 1.7 & 2.6 & 7.1 & 3.4 & 0.001 & 0.11 & & 0.05 & 0.9 & \\
\hline$X-40$ & 10 & 25.5 & & Bal. & & 7.5 & & & & 0.5 & & & & \\
\hline CM 186 & Bal. & 6.6 & 5.7 & 9.2 & 3.2 & 8.5 & 0.5 & 0.7 & 0.01 & 0.07 & 1.4 & & & \\
\hline MarM 247 & Bal. & 8.2 & 5.4 & 9.9 & 3.0 & 9.8 & 0.7 & 1.05 & 0.01 & 0.13 & 1.3 & 0.4 & 0.2 & \\
\hline CMSX-4 & Bal. & 6.5 & 5.6 & 9.0 & 6.5 & 6.0 & 0.6 & 1.0 & & & 0.1 & & & 3.0 \\
\hline N5 & Bal. & 7.0 & 6.2 & 7.5 & 6.5 & 6.0 & 0.6 & 1.0 & & & 0.1 & & & 3.0 \\
\hline PWA 1484 & Bal. & 5.0 & 5.6 & 10.0 & 8.7 & 6.0 & 2.0 & & & & 0.1 & & & 3.0 \\
\hline
\end{tabular}

PWA $1484 @ 700^{\circ} \mathrm{C}$ Wet and Dry

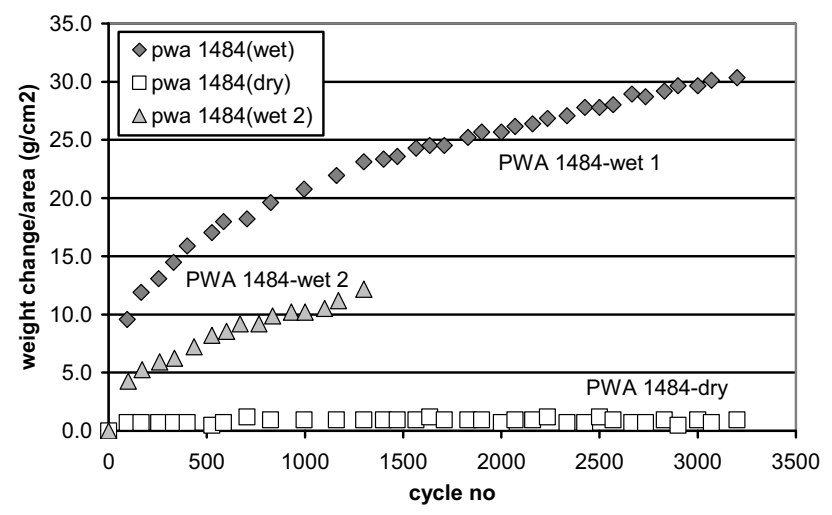

N5 @700 ${ }^{\circ} \mathrm{C}$ Wet and Dry

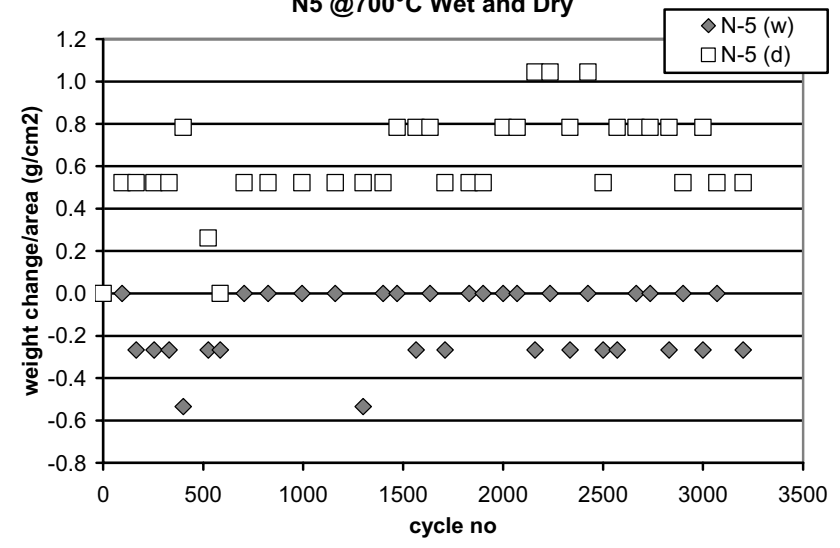

CM $186 @ 700^{\circ} \mathrm{C}$ Wet and Dry

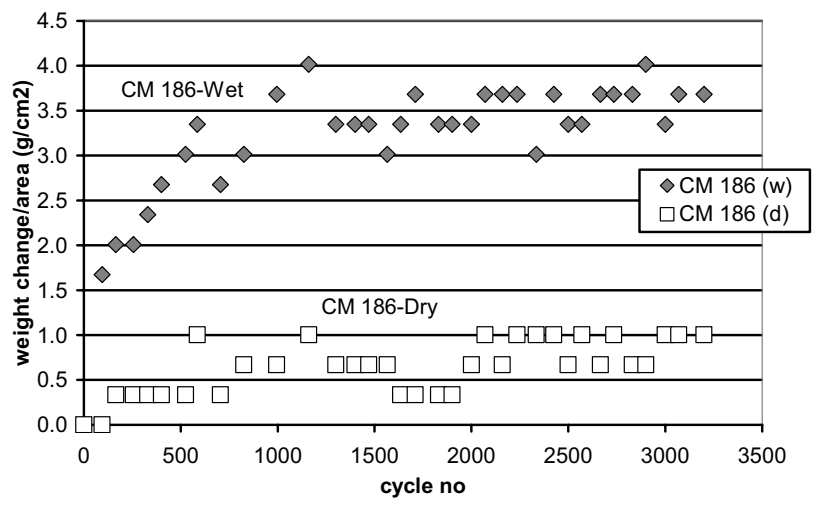

MarM $247 @ 700^{\circ} \mathrm{C}$ Wet and Dry

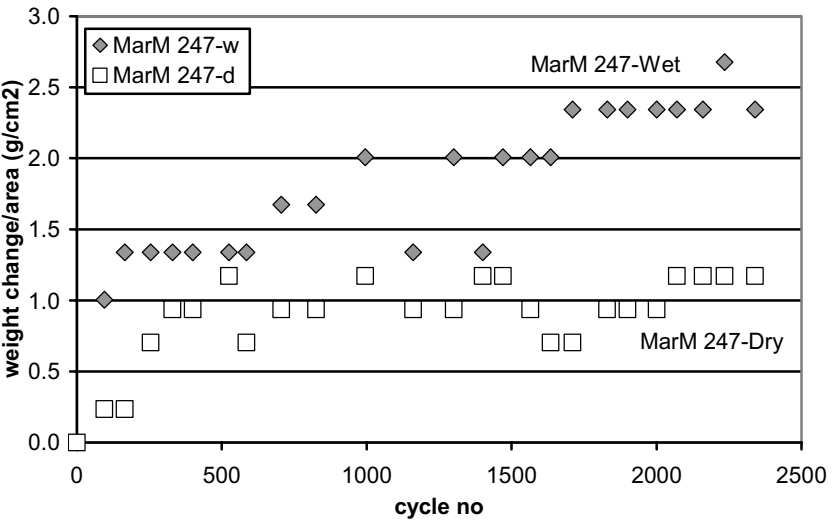

Figure 1. Weight change versus time data for the cyclic oxidation of some nickel base superalloys in dry and in wet air $(0.3$ atm water vapor) at $700^{\circ} \mathrm{C}$.

behavior of low sulfur N5. Metallographic examination of the exposed specimens showed that an adherent layer of $\alpha-\mathrm{Al}_{2} \mathrm{O}_{3}$ was present on low sulfur $\mathrm{N} 5$, but a scale intermixed with $\mathrm{NiO}$, $\mathrm{Cr}_{2} \mathrm{O}_{3}$ and $\alpha-\mathrm{Al}_{2} \mathrm{O}_{3}$ was formed on the higher sulfur-containing N5, Figure 9.

The results that have been obtained with the $\alpha$-alumina forming superalloys show that water vapor has two major effects on the oxidation of these alloys. In particular, the presence of water vapor adversely affects the selective oxidation of aluminum in these alloys and this adverse effect is more pronounced at $700^{\circ} \mathrm{C}$ compared to $1000^{\circ} \mathrm{C}$. Water vapor also causes the $\alpha-\mathrm{Al}_{2} \mathrm{O}_{3}$ scales to crack and spall. This effect is most severe on alloys for which the $\alpha-\mathrm{Al}_{2} \mathrm{O}_{3} /$ alloy interfacial toughness is low (e.g. N5 with 5-8 ppm sulfur compared to N5 with less than $1 \mathrm{ppm}$ sulfur).The adverse effect of water vapor on the selective oxidation of aluminum appears to become more severe as the temperature is decreased. For example, in the case of PWA 1484 and $\mathrm{CM} 186$ continuous layers of $\alpha-\mathrm{Al}_{2} \mathrm{O}_{3}$ were not developed at $700^{\circ} \mathrm{C}$ in water vapor, Figure 4 , but continuous layers of $\alpha$ $\mathrm{Al}_{2} \mathrm{O}_{3}$ were evident on these alloys at $900^{\circ} \mathrm{C}$, Figure 5 . Nevertheless, it does appear that some adverse effects of water vapor on selective oxidation of aluminum do occur even at temperatures as high as $1100^{\circ} \mathrm{C}$. Such effects are evident in Figure 10 where a Ni-8Cr-6Al (wt\%) alloy was oxidized for 1 hour in dry air and air with 0.1 atm water vapor. In dry air a 
continuous layer of $\alpha-\mathrm{Al}_{2} \mathrm{O}_{3}$ was formed, Figure 10a, whereas much more transient oxidation occurred in a similar exposure time with the wet exposure, Figure 10b. The results that have been obtained show that the selective oxidation of aluminum in all of the alloys is less effective when water vapor is present. In the cyclic oxidation tests there is some spalling of the $\alpha-\mathrm{Al}_{2} \mathrm{O}_{3}$ scales and the subsequent oxidation causes the scales to be enriched in elements that are more noble compared to aluminum.
PWA $1484 @ 900^{\circ} \mathrm{C}$ Wet and Dry

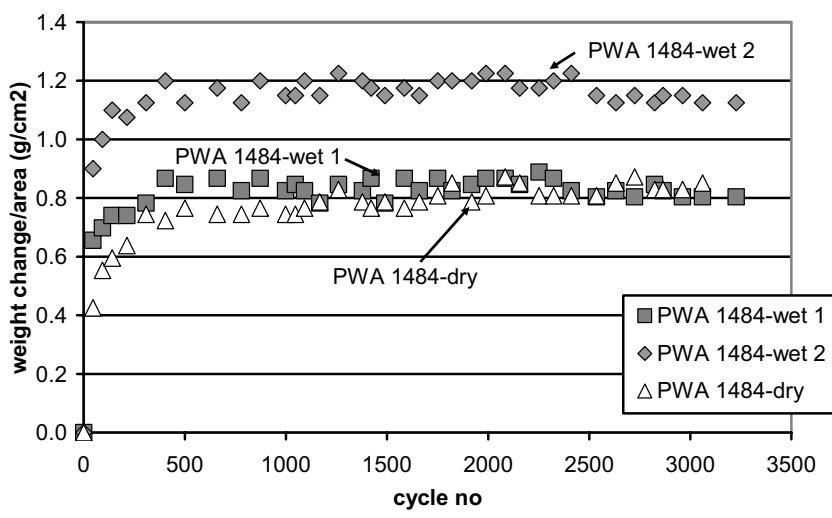

N5 @ $900^{\circ} \mathrm{C}$ Wet and Dry

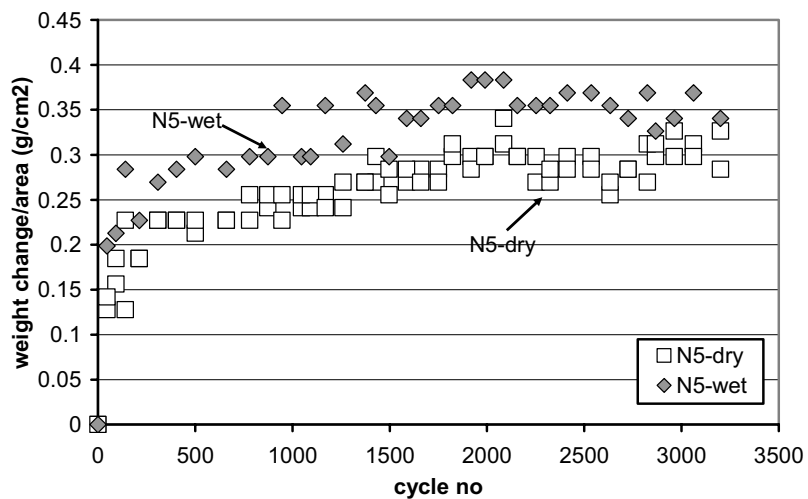

CM $186 @ 900^{\circ} \mathrm{C}$ Wet and Dry

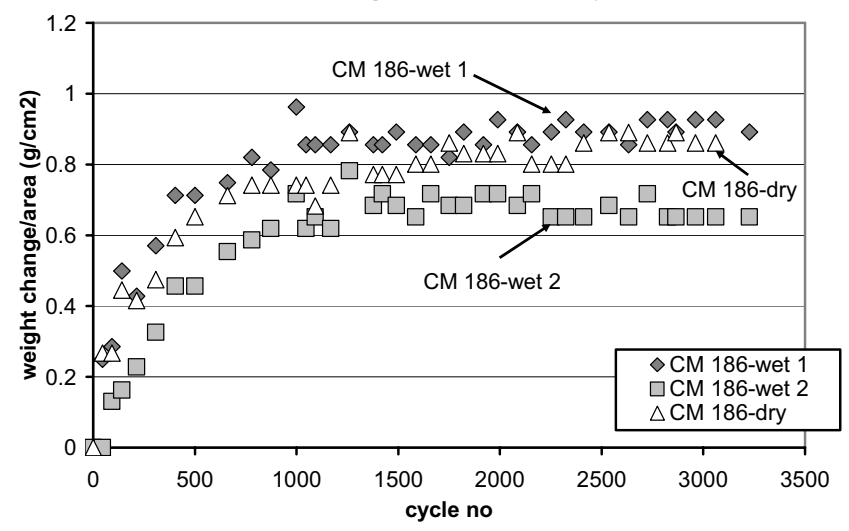

MarM $247 @ 900^{\circ} \mathrm{C}$ Wet and Dry

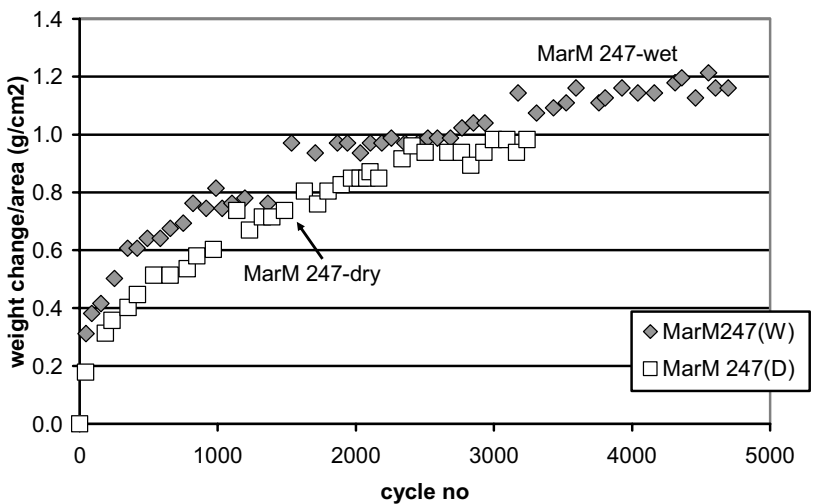

Figure 2. Weight change versus time data for the cyclic oxidation of some nickel base superalloys in dry and in wet air ( 0.3 atm water vapor) at $900^{\circ} \mathrm{C}$.
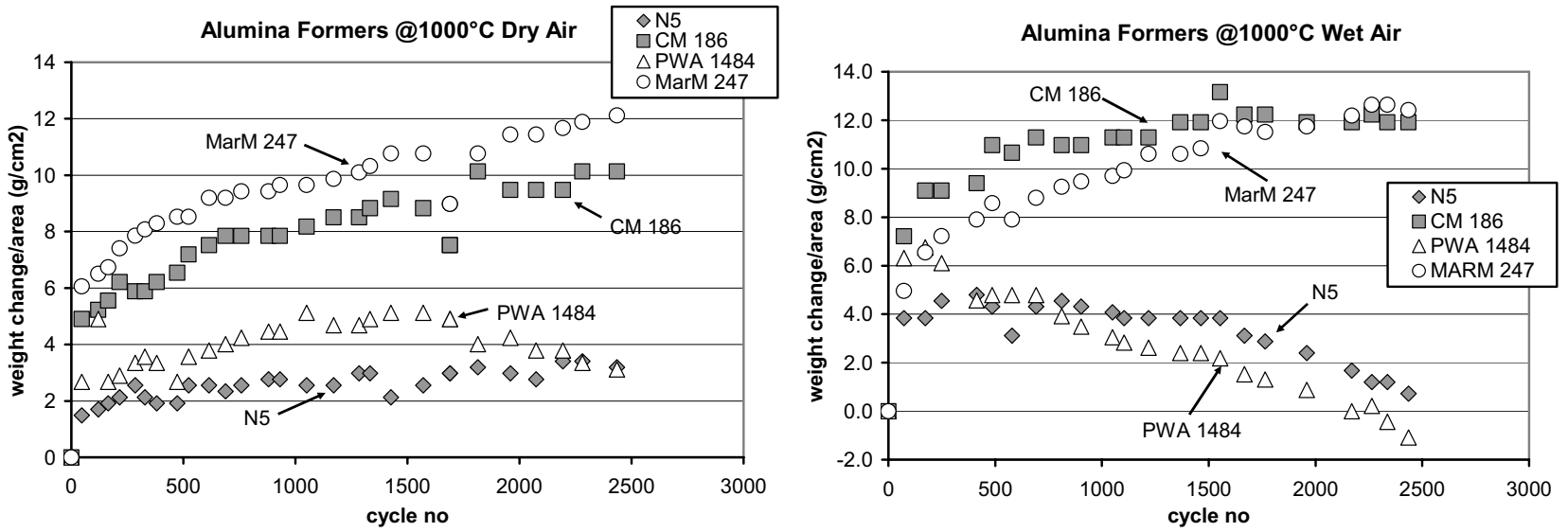

Figure 3. Weight change versus time data for the cyclic oxidation of some nickel base superalloys in dry and in wet air $(0.3$ atm water vapor) at $1000^{\circ} \mathrm{C}$. 


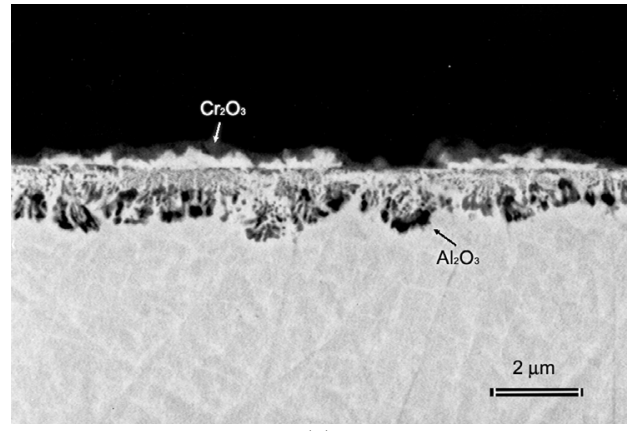

(a)

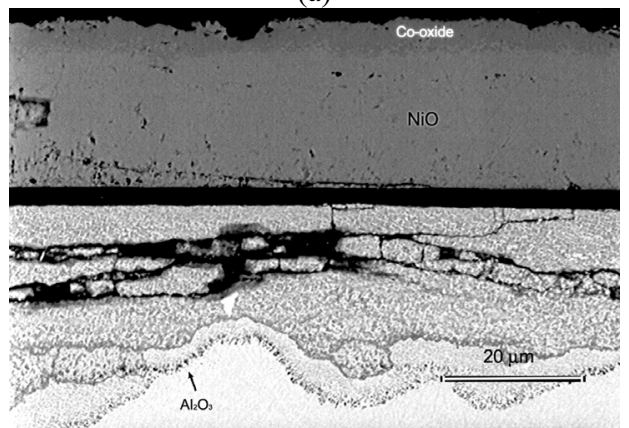

(b)

Figure 4. SEM micrographs showing the cross section of PWA 1484 after 3200 hours of cyclic exposure at $700^{\circ} \mathrm{C}$ (a) in dry, and (b) in wet air. Continuous alumina layers were also not present on the other alumina formers (i.e. MarM 247, CM 186 and René N5). However, the thickness of the transient oxide layer that formed on these alloys was less compared to PWA 1484, René N5 being the thinnest.

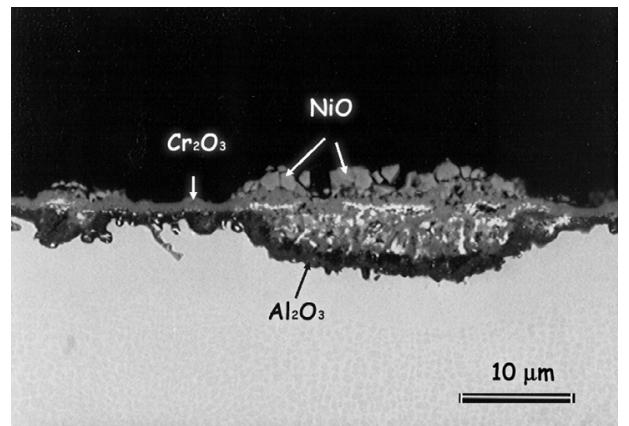

(a)

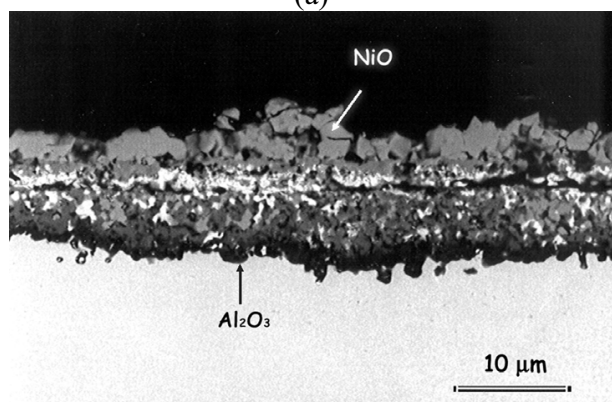

(b)

Figure 5. SEM micrograph showing the cross section of CM 186 at $900^{\circ} \mathrm{C}$ (a) in dry, and (b) in wet air after 3200 cycles. Similar microstructures were observed on MarM 247, PWA 1484 and René N5.

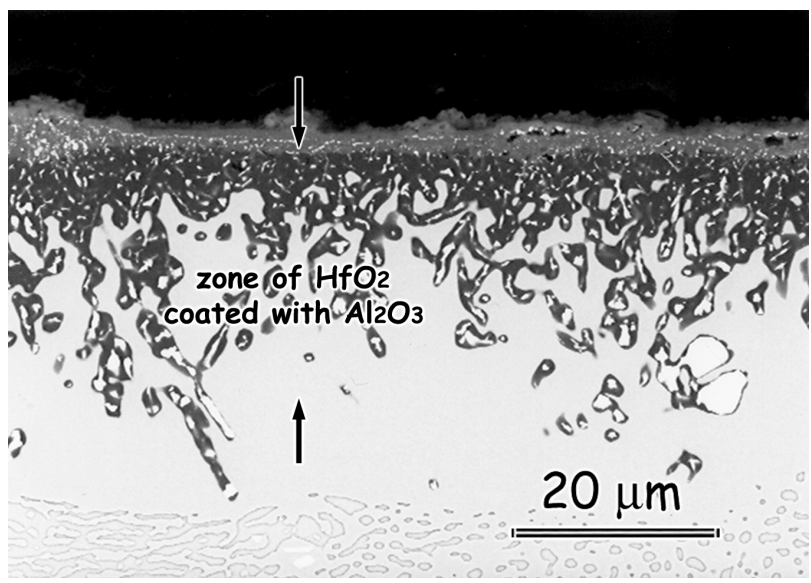

Figure 6. Scanning micrograph of CM 186 after cyclic oxidation for $2500 \mathrm{~h}$ in wet air $\left(\mathrm{PH}_{2} \mathrm{O}=0.3 \mathrm{~atm}\right)$ at $1000^{\circ} \mathrm{C}$.

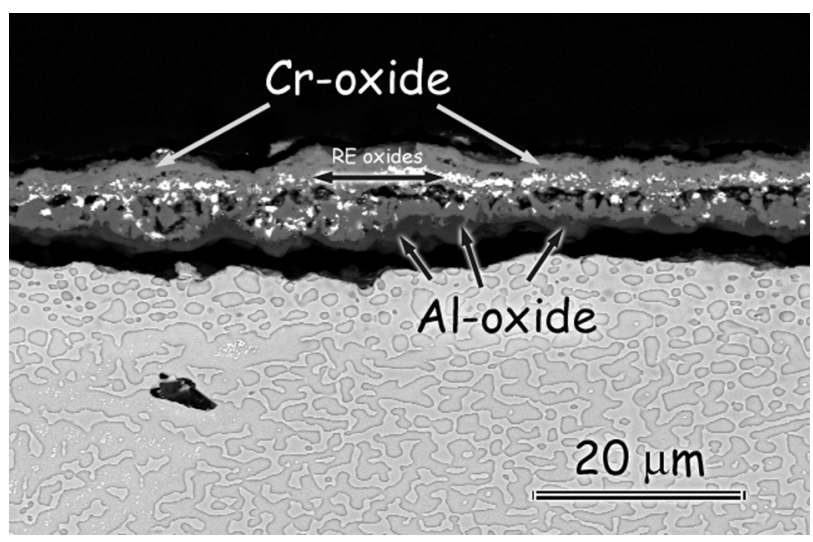

Figure 7. SEM micrograph of N5 after cyclic oxidation at $1000^{\circ} \mathrm{C}$ in wet air for 2500 cycles.

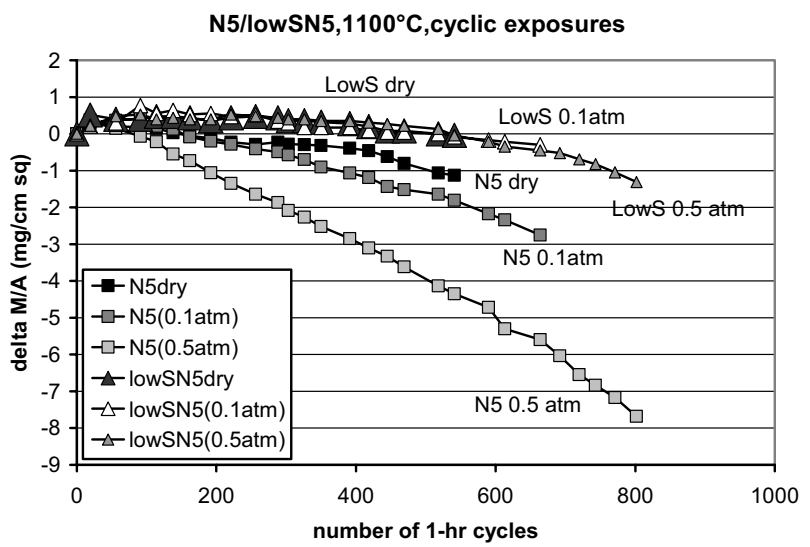

Figure 8. Weight change versus time measurements for N5 specimens (low $\mathrm{S}$ and regular $\mathrm{S}$ ) cyclically oxidized in dry and in wet air at two water vapor pressures $(0.1 \mathrm{~atm}$ and $0.5 \mathrm{~atm})$ at $1100^{\circ} \mathrm{C}$. 


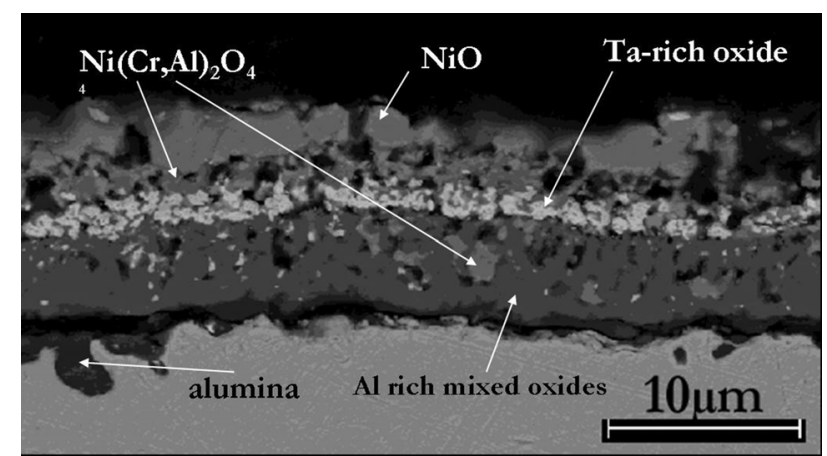

(a)

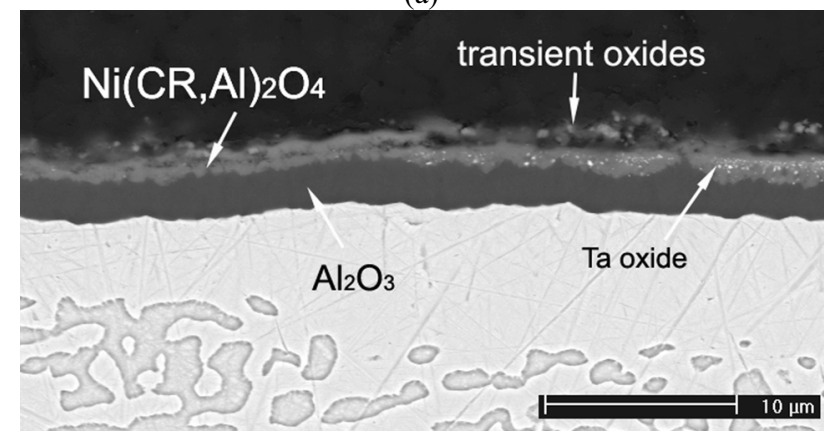

(b)

Figure 9. N5 exposed for 802 cycles at $1100^{\circ} \mathrm{C}$ in wet air $(0.5$ atm water vapor): (a) alloy with normal sulfur content, (b) alloy with low sulfur content.
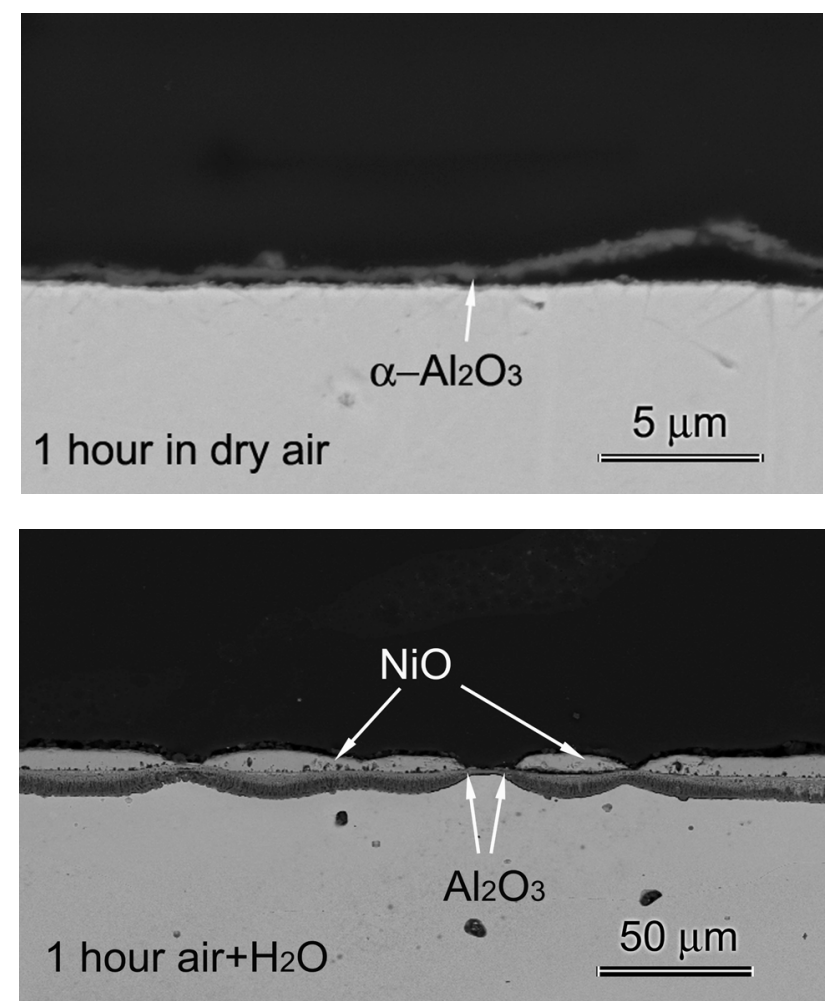

Figure 10. Cross-section of $\mathrm{Ni}-8 \mathrm{Cr}-6 \mathrm{Al}$ oxidized for $1 \mathrm{~h}$ at $1100^{\circ} \mathrm{C}(\mathrm{a})$ in dry air, and (b) in air with water vapor $(0.1 \mathrm{~atm})$.
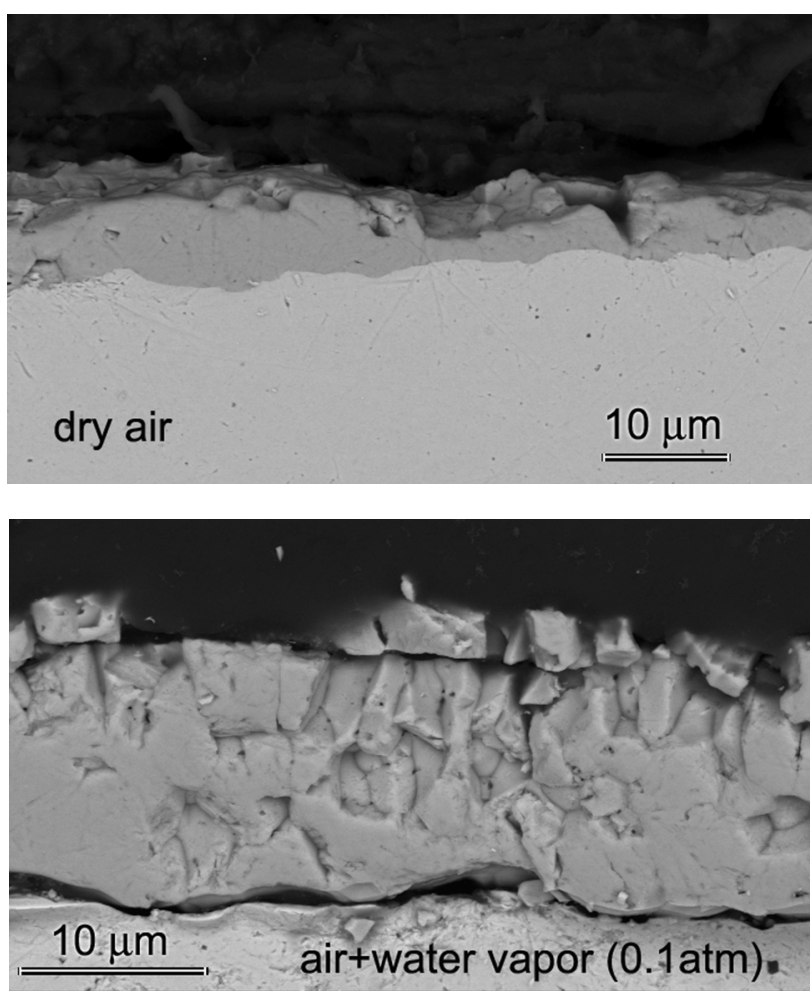

Figure 11. Ni 99.999 pct pure, exposed for $1 \mathrm{~h}$ at $1100^{\circ} \mathrm{C}$ in two different atmospheres (SEM cross-sectional images, showing morphology and thickness of $\mathrm{NiO}$ scales).

The detrimental influence of water vapor on the selective oxidation of aluminum may be the result of more rapid growth of the transient oxides in the presence of water vapor. Indeed, specimens of pure nickel (99.999 wt pct) were oxidized for 1 hour at $1100^{\circ} \mathrm{C}$ in dry air and in air with $0.1 \mathrm{~atm}$ water vapor. It was determined that the $\mathrm{NiO}$ scale thickness formed in air with water vapor was twice that formed in dry air, Figure 11.

\section{Chromia-Forming Superalloys}

Weight change versus time data for the cyclic oxidation of IN 738 and $\mathrm{X}-40$ at $700^{\circ} \mathrm{C}, 900^{\circ} \mathrm{C}$ and $1000^{\circ} \mathrm{C}$ in dry air and in air with water vapor are presented in Figures 12, 13 and 14. At $700^{\circ} \mathrm{C}$ it was not clear if there was a difference between the oxidation of IN 738 and X-40 in dry and wet air. Examination of the weight change versus time data indicated that there was some cracking and spalling of oxide but this appeared to be about the same in wet and dry air. Metallographic cross-sections of exposed IN 738 specimens showed external scales of $\mathrm{Cr}_{2} \mathrm{O}_{3}$ with internal stringers of alumina, Figure 15, for both dry and wet air. The thickness of $\mathrm{Cr}_{2} \mathrm{O}_{3}$ as well as internal oxide appeared to be thicker in wet compared to dry air. In the case of exposed X-40 specimens, Figure 16, an external layer of $\mathrm{Cr}_{2} \mathrm{O}_{3}$ was evident for specimens exposed in wet and dry air.

For oxidation at $900^{\circ} \mathrm{C}$ both IN 738 and X-40 were severely degraded in wet and dry air. The weight change versus time data showed larger weight losses for specimens exposed in wet air, Figure 13, but metallographic sections of exposed specimens 
IN $738 @ 700^{\circ} \mathrm{C}$ Dry and Wet

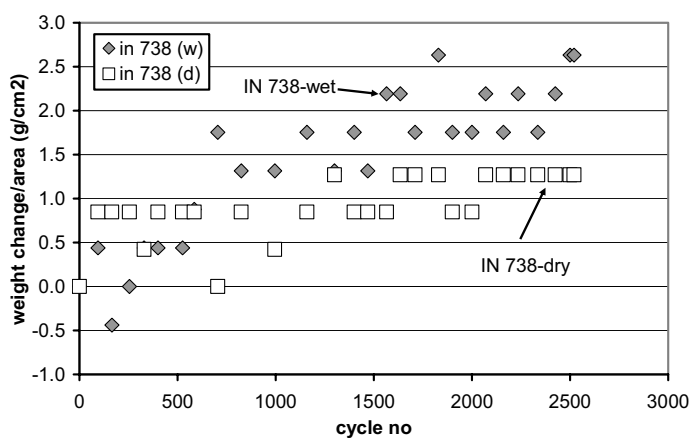

$\mathrm{X} 40 @ 700^{\circ} \mathrm{C}$ Wet and Dry

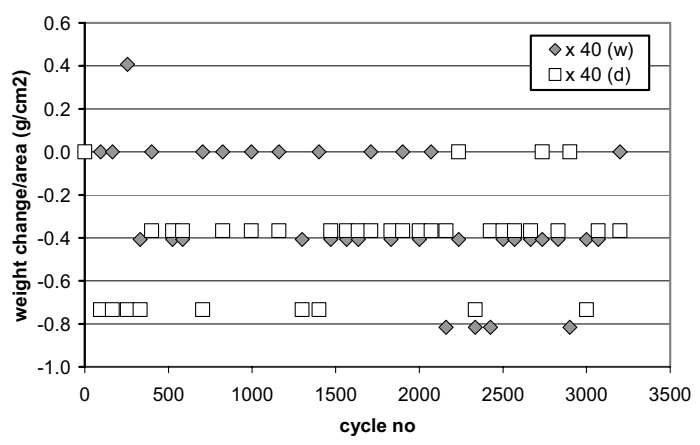

Figure 12. Weight change versus number of cycles plot for the cyclic oxidation of IN 738 and X-40 at $700^{\circ} \mathrm{C}$ at a total pressure of $1 \mathrm{~atm}$ in dry air and in air saturated with water vapor at 0.3 atm.

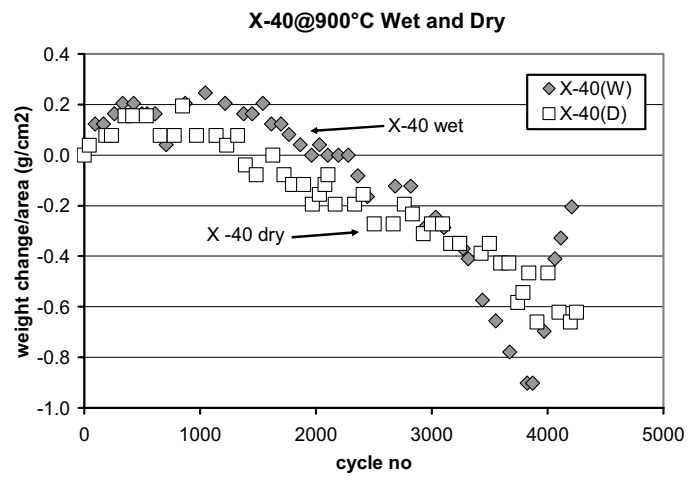

IN 738@900C Dry and Wet

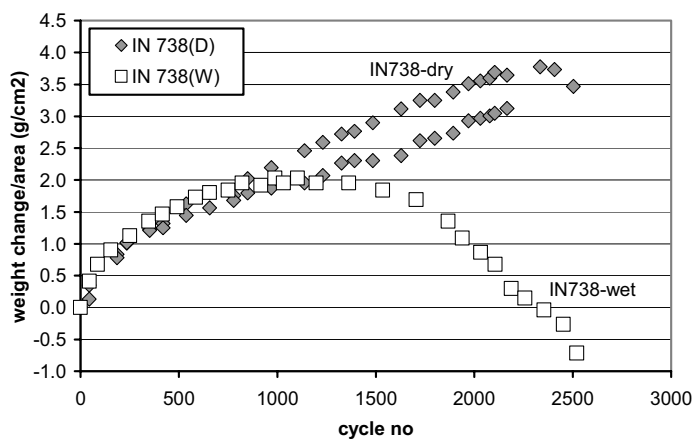

Figure 13. Weight change versus number of cycles plot for IN 738 and $\mathrm{X}-40$ at $900^{\circ} \mathrm{C}$ at a total pressure of 1 atm in dry air and in air saturated with water vapor at $0.3 \mathrm{~atm}$.
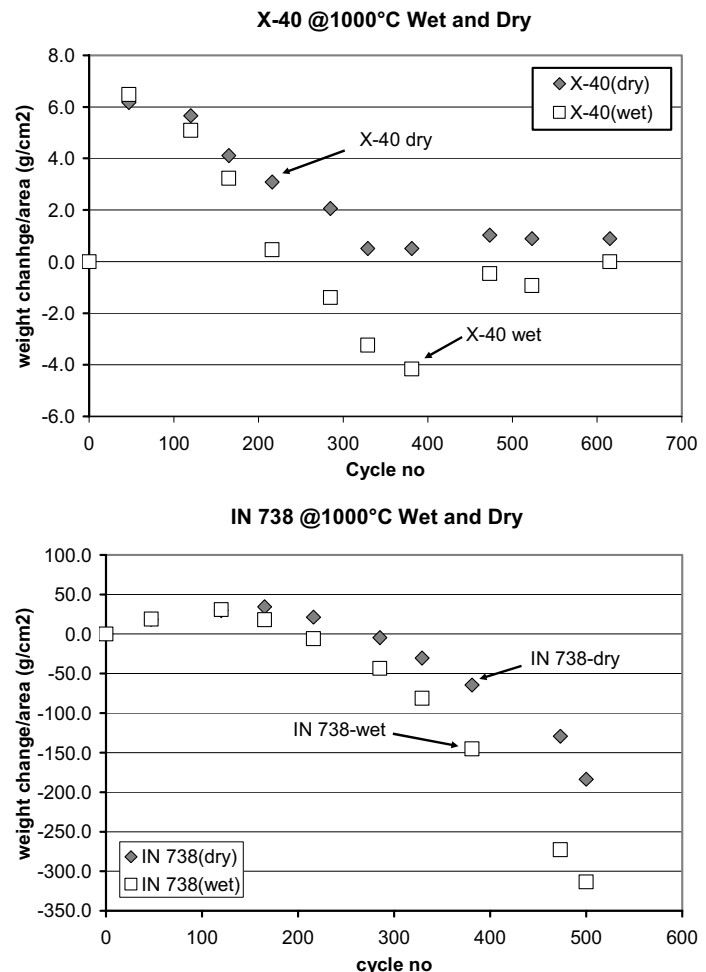

Figure 14. Weight change versus number of cycles plot for the cyclic oxidation of IN 738 and X-40 at $1000^{\circ} \mathrm{C}$ at a total pressure of $1 \mathrm{~atm}$ in dry air and in air saturated with water vapor at $0.3 \mathrm{~atm}$.

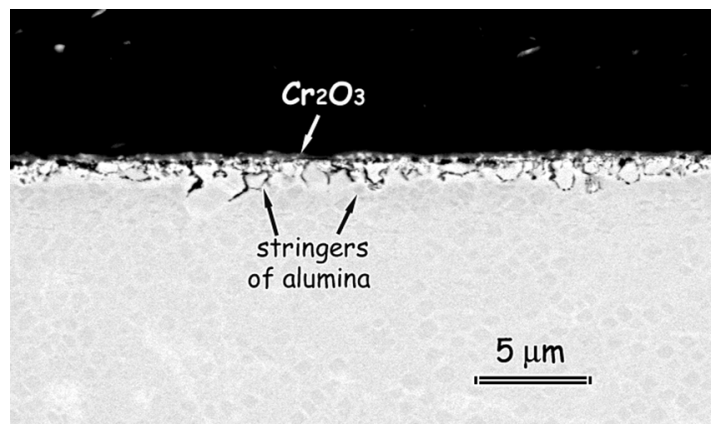

(a)

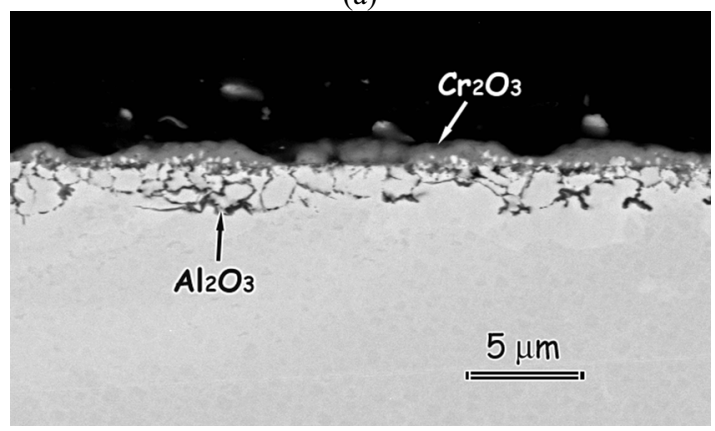

(b)

Figure 15. Cross-sectional micrograph of IN 738 after 2520 cycles at $700^{\circ} \mathrm{C}$ (a) in dry air, and (b) in air with $0.3 \mathrm{~atm}$ of water vapor. 


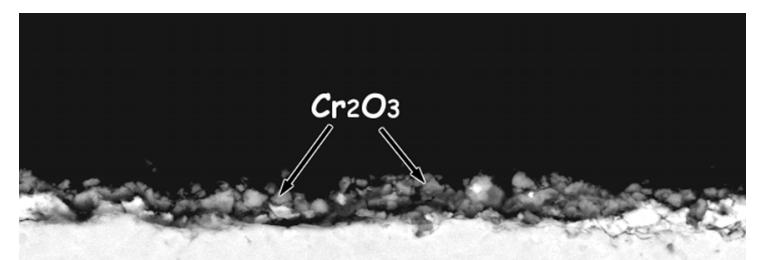

$5 \mu m$

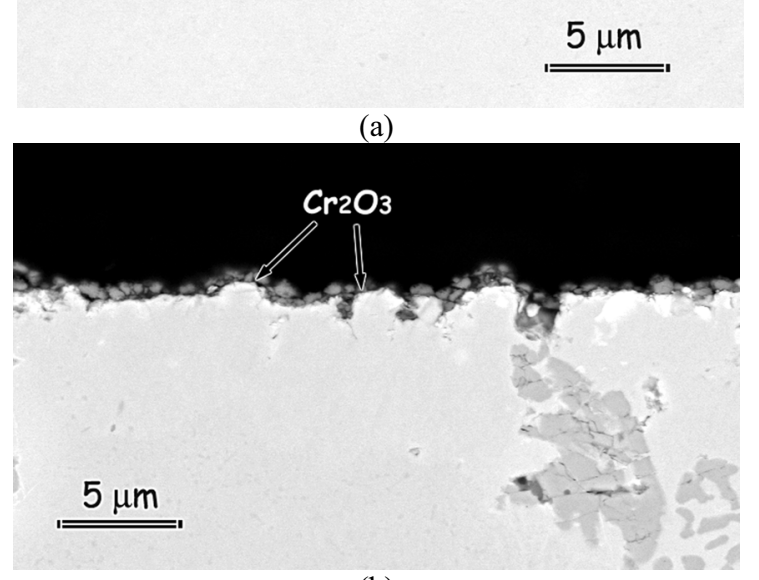

(b)

Figure 16. Cross-sectional micrograph of X-40 after 2520 cycles at $700^{\circ} \mathrm{C}$ (a) in dry air, and (b) in air with $0.3 \mathrm{~atm}$ of water vapor.

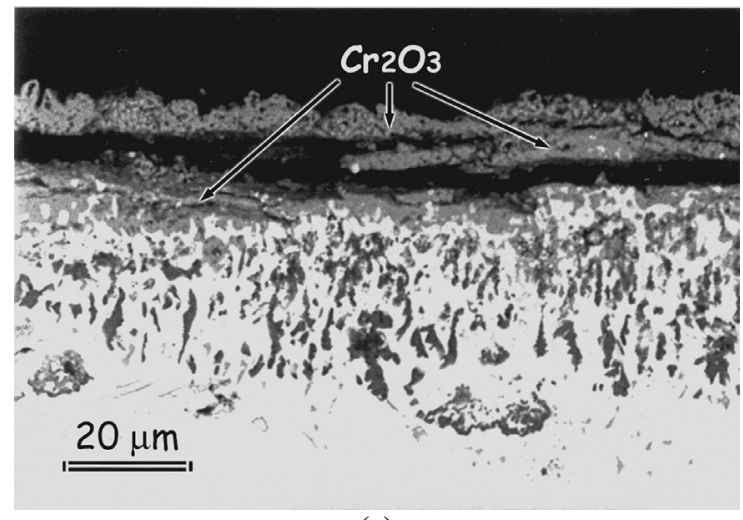

(a)

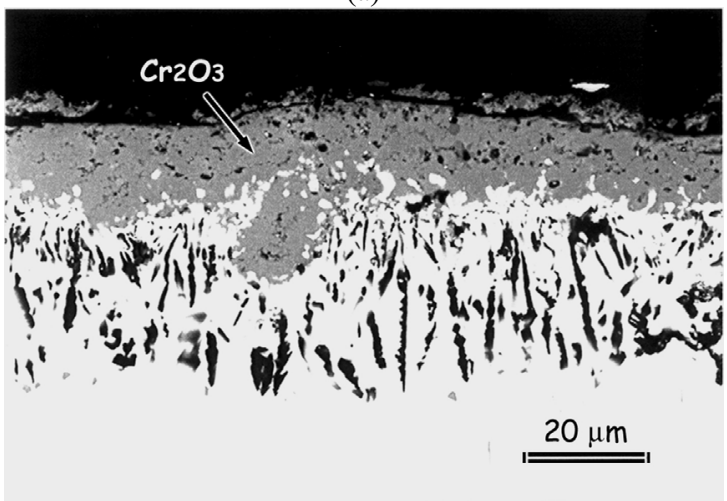

(b)

Figure 17. Cross-sectional micrographs of IN 738 after 2520 cycles at $900^{\circ} \mathrm{C}$ (a) in dry air, and (b) in air with a water vapor pressure of $0.3 \mathrm{~atm}$. showed significant amounts of degradation in dry air, Figure 17 and 18 , had also occurred. In order to examine the degradation of these alloys at $900^{\circ} \mathrm{C}$ in more detail a $\mathrm{Ni}-30 \mathrm{Cr}$ alloy was cyclically and isothermally oxidized in wet and dry air at $900^{\circ} \mathrm{C}$. As can be seen in Figure 19 the weight losses observed for the cyclic oxidation of this alloy are greater for wet air than dry air. However, the weight changes for cyclic oxidation in dry air are less than those for isothermal oxidation. Such results show that there is some cracking and spalling of the $\mathrm{Cr}_{2} \mathrm{O}_{3}$ from this alloy in the dry cyclic test. The isothermal oxidation kinetics for Ni$30 \mathrm{Cr}$ in wet air are presented in Figure 20. It can be seen that after an initial period of weight gain, there is a linear weight loss, which must be due to volatization of $\mathrm{Cr}_{2} \mathrm{O}_{3}$ in the wet gas. The vaporization of $\mathrm{Cr}_{2} \mathrm{O}_{3}$ in dry air appears to be negligibly small. The weight loss observed in the wet isothermal test match quite well the weight losses observed for cyclic oxidation of $\mathrm{Ni}$ $30 \mathrm{Cr}$ in wet air at $900^{\circ} \mathrm{C}$, Figure 20 . These results obtained with $\mathrm{Ni}-30 \mathrm{Cr}$ at $900^{\circ} \mathrm{C}$ show there is some weight loss in dry air due to spalling of oxide. There are also probably weight losses for this alloy due to spalling of oxide during cyclic oxidation at $900^{\circ} \mathrm{C}$ in wet air, but these weight losses are predominantly due to vaporization of $\mathrm{Cr}_{2} \mathrm{O}_{3}$ in the wet environment. It is believed that similar processes are dominant during cyclic oxidation of both IN 738 and X-40 at $900^{\circ} \mathrm{C}$ in wet and dry air.

At $1000^{\circ} \mathrm{C}$ during cyclic oxidation of both IN 738 and X-40, the degradation was severe. The weight losses for IN 738 were very large with not a large difference between wet and dry air, Figure

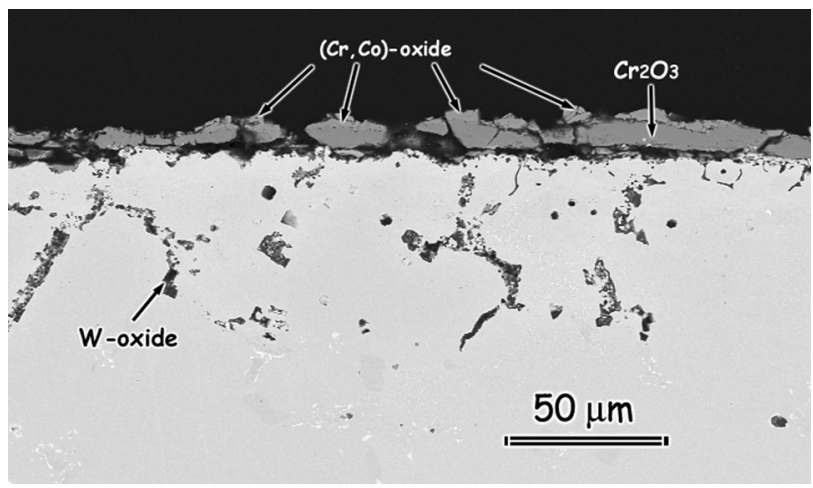

(a)

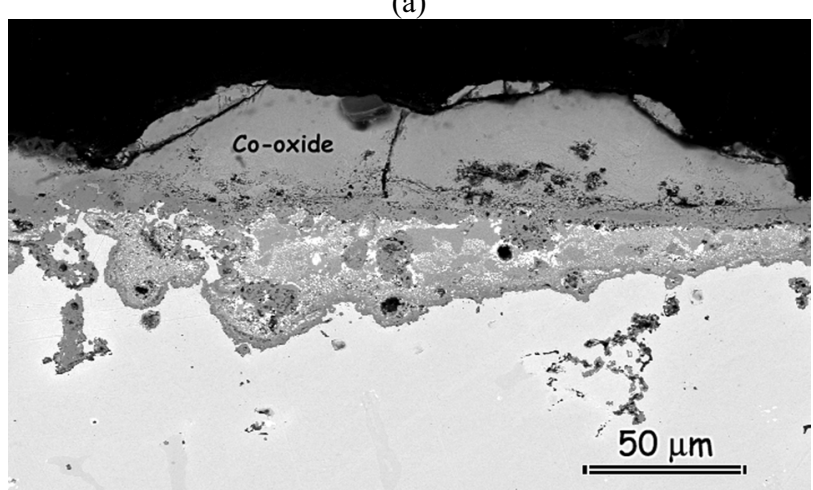

(b)

Figure 18. Cross-sectional micrographs of X-40 after 4250 cycles at $900^{\circ} \mathrm{C}$ (a) in dry air, and (b) in air with 0.3 atm of water vapor. 


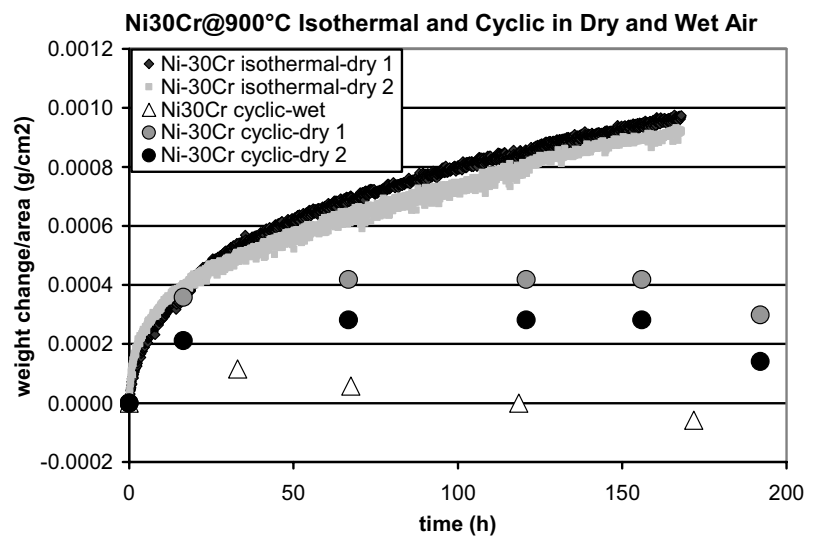

Figure 19. Weight change versus time measurements for the cyclic oxidation of $\mathrm{Ni30 \textrm {Cr }}$ at $900^{\circ} \mathrm{C}$ in dry and wet air, and for the isothermal oxidation of $\mathrm{Ni30Cr}$ in dry air.

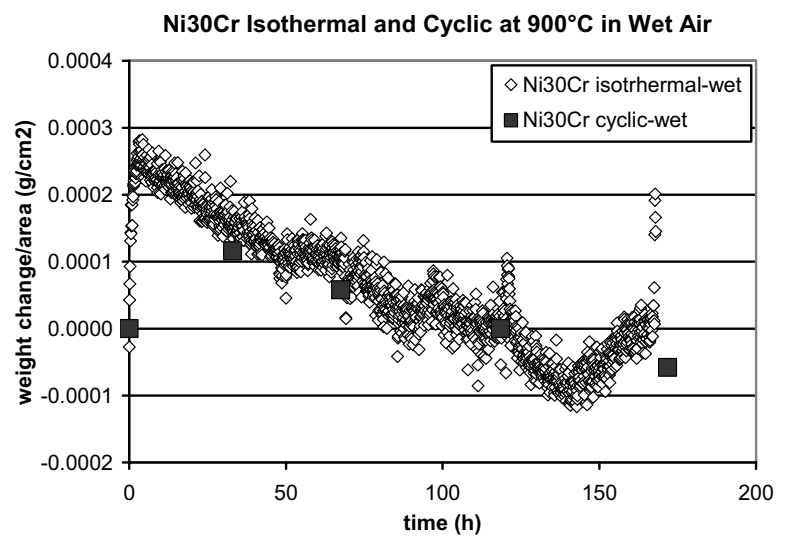

Figure 20. Weight change versus time measurements for the cyclic and isothermal oxidation of $\mathrm{Ni}-30 \mathrm{Cr}$ in wet air at $900^{\circ} \mathrm{C}$.

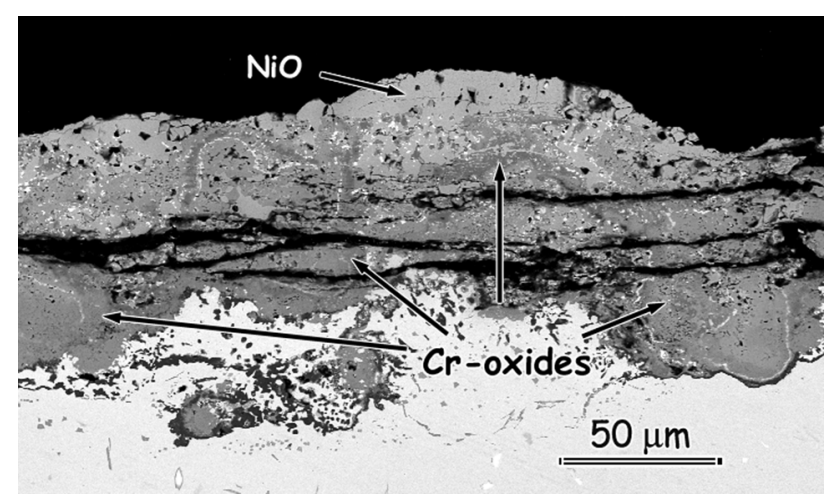

Figure 21. Cross-sectional micrograph of IN 738 after 500 cycles at $1000^{\circ} \mathrm{C}$ in air with water vapor at a pressure of $0.3 \mathrm{~atm}$.

14, and $\mathrm{NiO}$ was present in the oxide scale, Figure 21. The weight losses of X-40 were smaller than those observed for IN 738 , Figure 14, but the degradation of this alloy was substantial with substantial amounts of internal oxidation of carbide phases, Figure 22, in both wet and dry air.

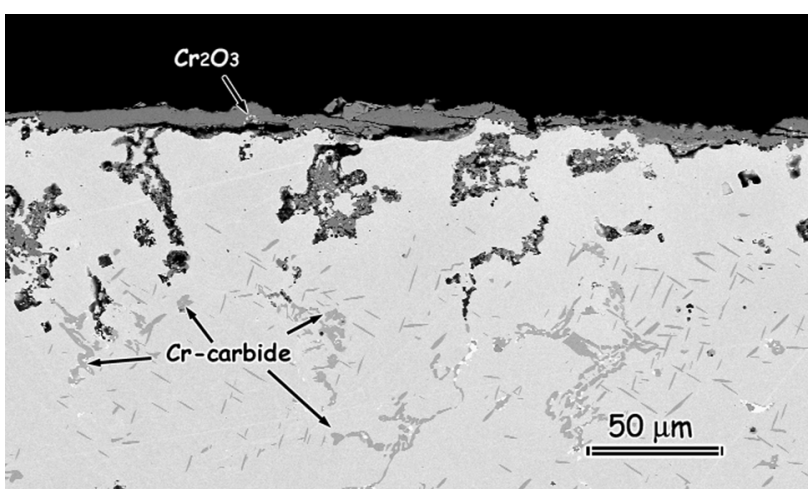

(a)

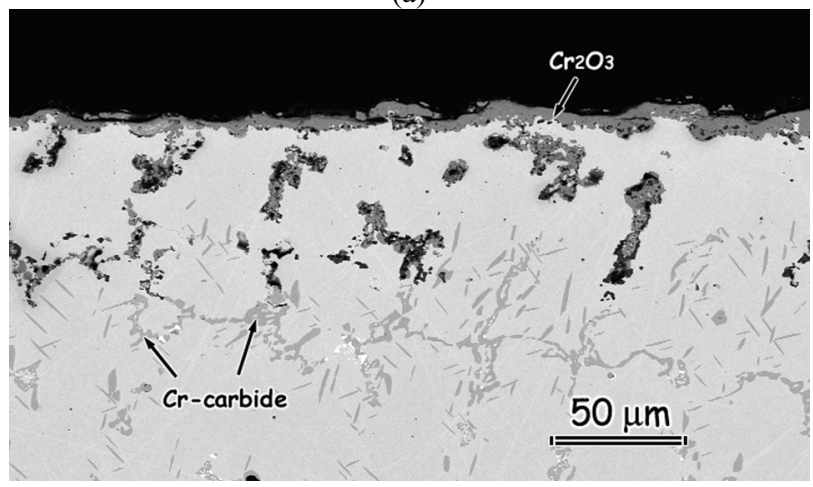

(b)

Figure 22. Comparison of cross-sectional micrographs of X-40 after 615 cycles at $1000^{\circ} \mathrm{C}$ (a) in dry air, and (b) in air with 0.3 atm water vapor.

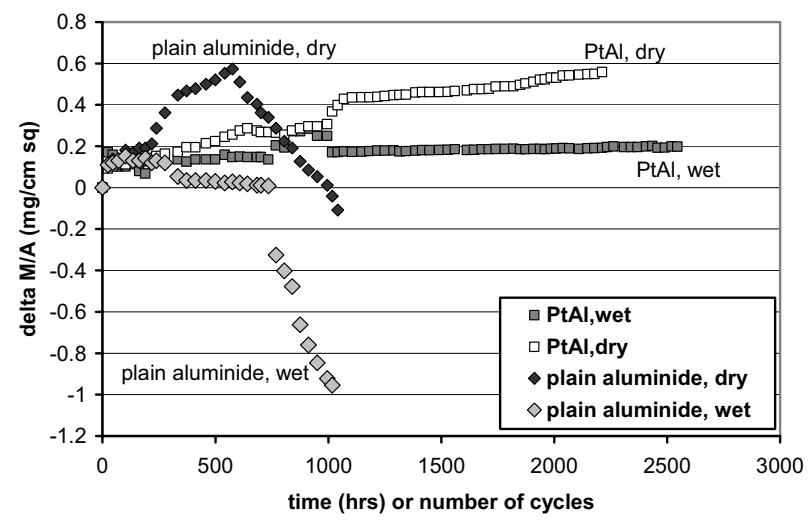

Figure 23. Change in mass vs time for aluminide coatings cyclically exposed at $1100^{\circ} \mathrm{C}$ in dry and wet $(0.1 \mathrm{~atm})$ air.

The results that have been obtained with the chromia-forming alloys show that these alloys are resistant to cyclic oxidation degradation at $700^{\circ} \mathrm{C}$ with no substantial effects of water vapor. On the other hand, these alloys are degraded rather severely at $900^{\circ} \mathrm{C}$. This occurs due to cracking and spalling of the $\mathrm{Cr}_{2} \mathrm{O}_{3}$ scales which is exacerbated in wet air due to the vaporization of $\mathrm{Cr}_{2} \mathrm{O}_{3}$ via the formation of hydrated chromium oxides (e.g. $\left.\mathrm{CrO}_{2}(\mathrm{OH})_{2}\right)[17]$. 


\section{Aluminide Coatings}

Both straight and platinum modified aluminide coatings on René $\mathrm{N} 5$ were cyclically oxidized at $1100^{\circ} \mathrm{C}$ in wet and dry air. The weight change versus time curves obtained for these tests are presented in Figure 23. The $\alpha-\mathrm{Al}_{2} \mathrm{O}_{3}$ scale that formed on the straight aluminide coating began to spall after about 200 cycles and the spalling was more severe in the test with water vapor, Figure 23. The $\alpha-\mathrm{Al}_{2} \mathrm{O}_{3}$ that formed on the platinum modified aluminide coating was very resistant to cracking and spalling in the cyclic test. Moreover, water vapor did not appear to exert a large effect on the spalling of $\alpha-\mathrm{Al}_{2} \mathrm{O}_{3}$ from this coating, Figure 23. These results show that cracking and spalling of the $\alpha-\mathrm{Al}_{2} \mathrm{O}_{3}$ scales is more severe in gases with water vapor and this effect becomes less dominant as the interfacial toughness of the $\alpha$ $\mathrm{Al}_{2} \mathrm{O}_{3}$-alloy interface becomes greater. Water vapor must cause the $\alpha-\mathrm{Al}_{2} \mathrm{O}_{3}$-alloy interfacial toughness to be decreased, but when this toughness is high, as occurs on platinum modified aluminide coatings, the magnitude of the toughness decrease is not sufficient to cause significant amounts of oxide scale to spall [16-18].

\section{Concluding Remarks}

Water vapor affects the oxidation characteristics of alloys that develop $\alpha-\mathrm{Al}_{2} \mathrm{O}_{3}$ or $\mathrm{Cr}_{2} \mathrm{O}_{3}$ scales for oxidation resistance in different ways. In the case of the $\alpha-\mathrm{Al}_{2} \mathrm{O}_{3}$ formers, water vapor adversely affects the selective oxidation of aluminum by causing more transient oxides such as $\mathrm{NiO}$ to be formed. Water vapor also causes $\alpha-\mathrm{Al}_{2} \mathrm{O}_{3}$ scales to spall during cyclic oxidation due to decreased toughness of the $\alpha-\mathrm{Al}_{2} \mathrm{O}_{3}$ interface. In the case of $\mathrm{Cr}_{2} \mathrm{O}_{3}$-formers, water vapor probably causes more transient oxides to be formed, but this effect is not substantial probably because of the higher chromium concentrations in the chromiaformers compared to the aluminum concentrations in the alumina-formers. Water vapor also causes more spalling of $\mathrm{Cr}_{2} \mathrm{O}_{3}$ scales from the chromia-formers, but the vaporization of $\mathrm{Cr}_{2} \mathrm{O}_{3}$ in water vapor causes much more degradation at temperatures of $900^{\circ} \mathrm{C}$ and above.

Considering applications for superalloys in environments containing water vapor, the chromia-formers should not be used at $900^{\circ} \mathrm{C}$ or above due to vaporization of $\mathrm{Cr}_{2} \mathrm{O}_{3}$. In the case of the alumina-forming superalloys, problems related to the development of $\alpha-\mathrm{Al}_{2} \mathrm{O}_{3}$ scales at low temperatures such as $700^{\circ} \mathrm{C}$ need to be addressed.

\section{Acknowledgment}

The authors gratefully acknowledge financial support of this work by the Office of Naval Research (Contract N00014-940085) and the South Carolina Energy Research and Development Center (Contract DE-F21-92 MC29061).

\section{References}

1. R. Janakiraman, G. H. Meier, and F. S. Pettit, Metall. Mater. Trans. A, vol. 30A (1999), 2905.

2. A. Rahmel, and J. Tobolski, Corr. Sci., vol 5 (1965),271.

3. C. W. Tuck, M. Odgers, and K. Sachs, Corr. Sci., vol. 9 (1969), 271.
4. R. L. McCarron, and J. W. Schulz, Proc. Symp. On High Temperature Gas-Metal Reactions in Mixed Environments, AIME, (New York, N.Y., 1973), 360.

5. H. Bouaouine, F. Armanet, and C. Coddet, Int. Cong. On Metallic Corrosion, (Toronto, Canada, 1989), 379.

6. I. Kvernes, M. Oliveira, and P. Kofstad, Corr. Sci., vol. 17 (1977), 237.

7. R. Kremer, and W. Auer, Mater. Corr. vol. 48 (1997), 35.

8. E. A. Irene, J. Electrochem. Soc., vol. 121 (1974), 1613.

9. J. F. Cullinan, Masters Thesis, (University of Pittsburgh, Pittsburgh, PA, 1989).

10. E. J. Opila, and R. E. Hann, J. Am. Ceram. Soc., vol 80 (1997), 197.

11. J. L. Smialek, R. C. Robinson, E. J. Opila, D. S. Fox, and N. S. Jacobson, Adv. Composite Mater., vol. 8 (1999), 33.

12. A. J. Sedriks, Corrosion of Stainless Steels, $2^{\text {nd }}$ ed., (John Wiley \& Sons, Inc. New York, N.Y., 1996).

13. P. Kofstad, Microscopy of Oxidation, (M. J. Bennett and G. W Lorrimer, eds, The Institute of Metals, London, 1991), 2.

14. H. Buscail, S. Heinze, P. Dufour, and J. P. Larpin, Oxid. Met., vol. 47 (1997), 445.

15. J. L. Smialek, Metall. Trans. A., vol. 22A (1991), 739.

16. M.C. Maris-Sida, G.H. Meier, and F.S. Pettit, Met. and Mat. Trans. A, 34A (2003), 2609.

17. K. Hilpert, D. Das, M. Miller, D. H. Peck, and R. Weiss, J. Electrochem Soc., 143 (1996), 3642.

18. K. Onal, M. C. Maris-Sida, G. H. Meier, and F. S. Pettit, Mat. at High Temp., 20 (2003), 327. 
